\title{
Igreja Católica, questão agrária e a luta social no campo (1950-1980)
}

Catholic Church, agrarian question and the social struggle in the countryside (1950-1980)

\author{
João Carlos Tedesco* \\ Emerson Neves Da Silva**
}

Palavras-chave: Igreja Católica Questão agrária Luta sociais

Keywords:

Catholic Church

Agrarian question Social struggle
Resumo: $\mathrm{O}$ artigo analisa alguns aspectos que evidenciaram a ação da Igreja Católica na configuração das lutas agrárias no Brasil entre as décadas de 1950 a 1980. Entendese ser um período efervescente de lutas sociais em torno do que se convencionou chamar de "questão agrária brasileira". O objetivo é demonstrar a mediação da referida instituição, as disputas internas, as ambiguidades nas ações e sua intensa influência na constituição e nas ações iniciais do Movimento dos Agricultores Sem Terra (MST). As fontes utilizadas foram leituras sobre o tema e o contexto político e econômico brasileiro do período, mas, em particular, boletins, documentos, cartas, relatórios, dentre outros, frutos de encontros, seminários e assembleias efetivados pela oficialidade da Igreja Católica e publicados pela CNBB no período em questão. As conclusões que se chega são que houve várias disputas no interior da instituição religiosa em torno das diretrizes de suas ações no horizonte social e no meio rural em particular; sempre houve uma preocupação com as questões que envolviam o pequeno agricultor e o modelo de desenvolvimento que produziam sua exclusão. Essa experiência de inserção social lhe deu credenciais para a mediação na efetivação do MST.

Abstract: The article analyzes some aspects that highlighted the action of the Catholic Church in the configuration of agrarian struggles in Brazil between the 1950s and 1980s. It is understood to be an effervescent period of social struggles around what has been called the "brazilian agrarian question". The objective is to demonstrate the mediation of the institution, the internal disputes, the ambiguities in the actions and their intense influence on the constitution and initial actions of the Landless Farmers Movement (MST). The sources used were readings on the theme and the Brazilian political and economic context of the period, but in particular, bulletins, documents, letters, reports, among others, the fruits of meetings, seminars and assemblies held by the official of the Catholic Church and published by CNBB for the period in question. The conclusions reached are that there were several disputes within the religious institution over the guidelines of its actions in the social horizon and in the rural area in particular; There has always been concern about the issues surrounding the small farmer and the development model that produced his exclusion. This experience of social insertion gave him credentials for mediation in the implementation of the MST.

Recebido em 18 de novembro de 2019. Aprovado em 12 de dezembro de 2019.

\footnotetext{
* Doutor em Ciências Sociais pela Universidade Estadual de Campinas (UNICAMP), pós-doutorado nas Universidade de Verona e Milão. Professor do Programa de Pós-Graduação em História da Universidade de Passo Fundo (UPF). Pesquisador do tema das migrações, dos processos de colonização no norte do Rio Grande do Sul e de conflitos agrários. E-mail: <jctedesco@upf.br>.

** Doutor em História Universidade do Vale do Rio dos Sinos (UNISINOS); professor do Programa de Pós-graduação em História da Universidade Federal da Fronteira Sul (UFFS). E-mail: <emerson.silva@uffs.edu.br>.
} 


\section{Introdução}

Os movimentos sociais são instâncias populares de transformações sociais; participam direta ou indiretamente da luta política de um país e contribuem para o desenvolvimento e a transformação da sociedade civil e política (GOHN, 2002). Os mesmos participam da mudança social histórica de um país. Porém, o caráter de suas transformações geradas poderá ser tanto progressista quanto conservador, dependendo das forças sociopolíticas que estão articulados em suas densas redes e dos projetos políticos que constroem com suas ações.

No campo dos movimentos sociais de luta pela terra, em seu nascedouro, no Brasil, não se pode não reconhecer o papel da Igreja Católica. A relação dela com os movimentos sociais é complexa, constituindo-se numa relação política perpassada por questões, econômicas, sociais, culturais e, também, de concepção religiosa. Por isso, perceber os antecedentes históricos relacionados ao posicionamento da referida instituição a respeito de problemas sociais, em especial da questão agrária, é fundamental para compreendemos, por exemplo, o processo de formação do Movimento dos Trabalhadores Sem Terra (MST) e sua imbricação com atividades pastorais desenvolvidas no sul do Brasil e a intensa mediação da referida instituição junto a esse sujeito social, bem como outros movimentos de representação e organização de pequenos agricultores surgidos no Brasil pós-regime civil-militar. Não podemos deixar de mencionar, também, que a Igreja Católica, historicamente, sempre esteve identificada com o meio rural e, principalmente, com os pequenos agricultores, pois é esse cenário que alimentou - e continua - valores ligados a uma cultura religiosa, sociabilidade comunitária e, em parte, familiar, sendo esse espaço, sobretudo, um viveiro de vocações sacerdotais e religiosas.

As décadas que contemplam o presente texto, em particular, as de 1950 e 1960, em nível de país e de América Latina, serão paradigmáticos em termos de alterações e redefinições econômicas, de desenvolvimento, no campo urbanístico e de produção, tanto no espaço urbano, quanto no meio rural. Havia uma estrutura de condições políticas e demandas sociais reprimidas que pressionavam para a produção de alterações no quadro social e econômico. O capital modernizante produzia suas contradições e mostrava sua face perversa, excludente. Os conflitos não tardaram a aparecer. Para fazer frente a essas questões de cunho social, em particular, no meio rural, a Igreja Católica intensifica dinâmicas pastorais, imprime ações diretamente no cenário onde os problemas se evidenciam e, passa a ser a grande mediadora nas demandas de grupos subalternizados.

Tendo isso presente, o objetivo do presente texto é problematizar a relação histórica dessa instituição com o que se convencionou chamar de "questão agrária brasileira" (GEHLEN, 1983), principalmente em torno da concepção de propriedade, de justiça social, de organização dos pequenos agricultores, da reforma agrária, etc. Buscamos dar ênfase às diretrizes das ações implementadas pela oficialidade da Igreja Católica através de documentos, cartas, relatórios, frutos de encontros, seminários, assembleias, dentre outros. Nossas fontes, além da revisão bibliográfica sobre o tema da luta pela terra e do contexto político brasileiro do período em questão, estão esses materiais elaborados pela $\mathrm{CNBB}$, os quais revelam o pensamento de membros da oficialidade institucional em torno do tema.

A intenção do texto, como já falamos, é entender os elementos preliminares que vão constituindo a sensibilização da entidade para a questão agrária brasileira, em particular, a que se refere aos pequenos camponeses, alijados pelas políticas públicas e pelo modelo de modernização tecnológica que se materializaram nas décadas de 1950 e 1960 em nível de país. Entendemos que a intensa mediação da Igreja Católica junto aos movimentos de luta pela terra no país, em particular, ao MST (Movimento dos Agricultores Sem Terra), em seu nascedouro no início da década de 1980 e, por quase duas décadas posteriores, deve-se, em grande parte, a essa construção histórica de uma experiência em torno do tema. Entendemos serem as décadas de 1950 e 1960 fundamentais nesse sentido. 
O texto está estruturado, primeiramente, analisando alguns aspectos que evidenciaram a ação da referida instituição religiosa na questão da terra em meados do século XX; posteriormente, analisa aspectos de uma nova ênfase institucional ligada ao processo de modernização, da lógica produtivista e da necessidade do pequeno agricultor se inserir nesse processo e permanecer no meio rural. $\mathrm{Na}$ sequência, a análise adentra para alguns aspectos do período do golpe civil-militar. Em boa parte desse período, a oficialidade da Igreja Católica revela uma performance ambígua no tocante às questões agrárias e, ao pequeno agricultor em particular. Por fim, nas décadas de 1970 e 1980, há um processo amplo de redefinição; nesse cenário são analisadas algumas pastorais, sua influência junto ao coletivo do MST e as redefinições desse junto à entidademãe. A análise conclui com alguns processos que revelam a presença da Igreja Católica no nascedouro do MST, porém, redefinida em anos posteriores à constituição desse coletivo de luta social.

\section{Os antecedentes históricos do envolvimento da Igreja Católica com a questão agrária - meados do século XX}

$\mathrm{Na}$ história da organização popular no Brasil, a década de 1950 revela-se expressiva; talvez seja fruto dos amplos processos de urbanização e industrialização brasileira, do esgotamento das fronteiras agrícolas, da inserção mais intensa e legalizada de partidos políticos e outras agremiações contrárias ao sistema capitalista e/ou ao seu formato do período, da presença da Igreja Católica já constituída enquanto organização estruturada e centralizada através da CNBB. Na realidade, é importante que se diga que, para as lutas em torno da terra, nunca houve uma estrutura de oportunidades políticas que lhe tenha sido favorável. A luta pela terra no Brasil sempre foi expressão de ações de repressão, mortes, torturas e assassinatos de muitas lideranças, quando não muitas das iniciativas de organização popular ficaram sob as cinzas e/ou clandestinas.
No caso em questão, a partir da segunda metade do século XX, a preocupação da Igreja Católica com temas relativos ao campo, como, por exemplo, a reforma agrária, toma voz institucional. Não se quer dizer que antes desse período não houvesse interesse da Instituição pelo tema, mas se tratava de outra conjuntura. A partir da década de 1950, houve uma mobilização das populações rurais em torno da reforma agrária, sobretudo sob influência de novos atores sociais, cabendo aos comunistas o papel de protagonistas na disputa pelo "controle" da população empobrecida do meio rural com a Igreja Católica em particular.

As Ligas Camponesas começam no nordeste brasileiro (Pernambuco) no início da década de 1950. Elas só conseguem ter uma grande expressão na luta por melhores condições de vida no meio rural no período posterior ao segundo governo Vargas. A pauta da reforma agrária passou a ganhar espaço no interior da agremiação, principalmente, quando ela esteve sob a liderança de Gregório de Bezerra e de Francisco Julião. Esse último tornouse uma grande expressão no interior do Partido Comunista Brasileira (PCB), em particular, nas questões que envolviam transformações na estrutura fundiária brasileira. Em pouco tempo, as Ligas ganham corpo maior, espalhando-se por várias regiões do país, formando sindicatos, organizando grupos de camponeses, em especial posseiros que historicamente foram excluídos e marginalizados do processo produtivo e da possibilidade de apropriação da terra. $\mathrm{O}$ partido Comunista (PCB), muito presente no interior das Ligas Camponesas, envolve-se também com o meio rural na luta pela reforma agrária, pela ruptura com a estrutura latifundista presente historicamente no país e seu poder político, na organização dos trabalhadores do campo. Esse processo todo vai se intensificar no início dos anos 60. Esse contexto de efervescência política, de propostas de desenvolvimento social e progresso econômico, de contradições sociais e da propriedade privada da terra, cria-se um complexo conjunto de relações de difícil solução, principalmente quando envolve a luta entre empobrecidos por políticas públicas e pelas estruturas sócio-jurídicas que ampararam a dimensão da grande propriedade da terra. 
Nesse cenário, a partir da década de 1950, a Igreja Católica apoiou a reforma agrária, porém, ao seu modo, talvez não em sintonia com propostas outras que, na década de 1950, fizeram-se sentir através das Ligas Camponeses, mais ao nordeste do país e ao Master (Movimento dos Agricultores Sem Terra) no Rio Grande do Sul, aquele capitaneado, em boa parte, pelo Partido Comunista e, esse último, pelo PTB do governador Brizola. No entanto, é interessante que se diga que esse apoio que indicamos da Igreja Católica consiste em duas fases bem distintas. No período anterior a 1964, a preocupação motiva-se pela prevenção às agitações que ameaçavam o campo (LENZ, 2002, p. 598). Com esse sentido, o bispo Dom Inocêncio Engelke, do município de Campanha (Minas Gerais), em 1950, inaugura a primeira proposta de reforma agrária da Igreja no Brasil, com o documento "Conosco, sem nós, ou contra nós, se fará a reforma agrária”, o qual sistematizou as discussões da Primeira Semana Ruralista da Diocese de Campanha, que contou com a participação de 60 párocos rurais, 250 fazendeiros, mais de 270 professoras rurais, religiosos e religiosas (CNBB, 1981a, p. 43-53). O documento chama a atenção para a necessidade de melhoria das condições de vida da população no campo, através da participação do trabalhador nos lucros da empresa agrícola e do acesso à propriedade privada. Caso contrário, se a Igreja Católica não perceber o perigo iminente da penetração de agitadores no meio rural, o documento sentencia: "Já perdemos os trabalhadores das cidades. Não cometamos a loucura de perder, também, o operariado rural" (CNBB, 1981a, p. 43-53).

\section{Disputas no interior do campo eclesiástico em torno da questão agrária}

No período em questão, há um sentimento anticomunista fortíssimo e explícito nos documentos oficiais da CNBB. Nesse sentido, houve uma cruzada ideológica da oficialidade da Igreja Católica para combater as ideias comunistas que estavam sendo disseminadas por partidos políticos, determinadas lideranças, bem como no interior dela mesma em torno de algumas pastorais consideradas mais progressistas. O cardeal Dom Vicente Scherer no Rio Grande do Sul foi o seu porta-voz, com grande atuação através de jornais, rádios, homilias, documentos e artigos escritos e assinados pela CNBB (RODEGHERO, 1998; BRUNEAU, 1979). $\mathrm{Na}$ história da Igreja Católica no Brasil, talvez, esse período do final da década de 1950 e início da de 1960 tenha sido o mais intenso nas ações contra a presença de agremiações e de ideias comunistas. $\mathrm{O}$ contexto político do período, a efervescência social produzida por instituições políticas e movimentos sociais, mas cima de tudo pela realidade vivida por grande parte dos pequenos agricultores no país. Havia uma grande mobilização das massas rurais por agremiações consideradas progressistas, as quais politizavam a pobreza e as desigualdades sociais. Essa politização é que preocupava a elite religiosa e oficial da Igreja Católica. Havia Bispos que se declaravam a favor da reforma agrária, da necessidade de exigência de justiça social. Documentos da CNBB de 1954 deixavam clara a preocupação social com a dignidade do homem do campo, porém, sem condenar abertamente o latifúndio.

Não obstante essa inquietação, a qual envolve concorrência da tutela de grupos sociais, em particular, os pequenos agricultores, a II Assembleia Ordinária da CNBB (Conferência Nacional dos Bispos do Brasil), por meio do documento A Igreja e a reforma agrária, em 1954, ressalta a pertinência de uma reforma agrária na vida rural, em especial no que diz respeito à posse e ao uso da terra e aos meios de vida da população empobrecida do meio rural, com identificação maior aos pequenos agricultores, nas suas várias manifestações regionais do país, com o objetivo de fixá-los a terra como proprietários. O documento apresenta o conceito de reforma agrária elaborado pela CNBB, o qual consiste no conjunto de medidas que modificam o atual estatuto jurídicosocial da propriedade rural, tendo como objetivo:

[...] vincular o homem a terra como seu proprietário; possibilitar em larga escala o acesso à terra àqueles que estejam aptos a se tornar proprietários e criar condições para que o homem 
obtenha, pela posse e uso adequado da terra, os meios de proporcionar uma existência digna a si e à família, sem ferir as legítimas exigências do bem comum (PAIVA, 1985, p. 88).

O desenvolvimento atrelado e dependente da segunda metade dos anos 1950, pregado e viabilizado pelo presidente Juscelino, encontrava eco no interior da oficialidade da Igreja por ser uma alternativa entre o ateísmo comunista e o "capitalismo iníquo". A ideologia cristã da encíclica Mater et Magistra (de 1961) dava respaldo nesse sentido. A Ação Católica (movimento no interior da Igreja Católica, já nascido em meados dos anos 40) se fortalece, legitima seu comprometimento com as transformações sociais, engajando-se na realidade social através dos vários movimentos (MATOS, 2003). Visões progressistas, em adequação com a dinâmica política e social do país, no interior do comando e da oficialidade da Igreja Católica, permitiram que isso se concretizasse. Renovação pastoral, mudança nas estruturas sociais, nova presença da Igreja na sociedade e o compromisso cristão com a realidade social, dão o tom desse período.

É igualmente verdade que no interior desses movimentos e no seu raio de atuação, se plasmou pouco a pouco uma relação fraternalmente evangélica entre militantes, dirigentes, sacerdotes e bispos, pois os membros do Ministério hierárquico atuavam antes de tudo como educadores de fé e recebiam dos militantes e dirigentes de instituições de inestimável valor sobre a realidade dos meios em que estes estavam inseridos [...]. (BARROS, 2002, p. 78).

A Igreja e o Estado, no período anterior ao golpe civil-militar, possuíam laços bastante estreitos. A instituição católica (CNBB), constituída em 52, tendo Dom Hélder Câmara na sua frente, em especial no Nordeste e no Sul do Brasil, buscava auxiliar o trabalhador rural em suas organizações e representações. O deslocamento dela para o "campo social" permitiu uma "reinterpretação da fé". Os movimentos de Educação de Base (MEB) em defesa da escola pública e também para o meio rural permitiram difundir informações, através de estações de rádio e produções literárias, na educação e formação de massas de camponeses (ALVES, 1979). O Concilio Vaticano II (1962-65) auxiliou na renovação para o âmbito social da Igreja Católica nesse período, em especial em sua preocupação com o rural, em seus planos de pastoral, em suas diretrizes para o mundo político (a Revolução Cubana de 59 produziu mais tensões internas) e para o mundo do trabalho (encíclicas papais contribuíram nesse sentido) (BEOZZO, 1994).

Nesse amplo contexto de embates e posições, outro elemento histórico importante no processo de desenvolvimento da compreensão e ação da Igreja sobre a questão agrária no Brasil foi o I Encontro dos Bispos do Nordeste. Reunidos em Campina Grande (PB), durante dois dias, no mês de maio de 1956, o encontro substanciou o Movimento Nordeste, ou seja, "o conjunto do comportamento político que configurou a união regional entre as classes subalternas, setores médios e certas frações da classe dominante" (PAIVA, 1985, p. 89). A essência do documento é o discurso sobre o Nordeste explorado, subdesenvolvido, e a proposta de um projeto de industrialização, via alteração da estrutura agrária (PAIVA, 1985, p. 89).

Cabe destacar que a repercussão do referido encontro se fez ecoar não somente na sociedade, mas também sobre o Estado; diretrizes elaboradas no encontro foram incorporadas pelo governo JK. Conforme Albert Hirschman, as autoridades eclesiais receberam a sanção da Presidência da República para a execução de vários projetos para comunidades por meio de grupos de trabalho, composto por representantes de diferentes agências. Esses grupos de trabalho ocupavam-se com projetos que iam desde o abastecimento e a purificação da água na cidade de Campina Grande, no sertão, até a melhor utilização de açudes e projetos de povoamento agrícola (HIRSCHMAN, 1965, p. 104). Sem dúvida, a Operação Nordeste, denominação desse movimento que envolveu o poder público federal e a Igreja Católica, embrião da Superintendência do Desenvolvimento do Nordeste (SUDENE), tem como um dos elementos constitutivos o I Encontro dos bispos do Nordeste (PAIVA, 1985, p. 90). Percebe-se, nesse sentido, 
uma comunidade de interesses entre a esfera governamental e a instituição católica no sentido de criar condições para a permanência de pequenos agricultores à terra, como proprietários, para evitar o êxodo rural, bem como a inserção política de grupos com outras filosofias sociais e religiosas, o que faria mal para as duas instituições em questão.

Já no II Encontro dos Bispos do Nordeste, realizado em Natal, em 1959, o conjunto do Episcopado da região considerou grave a situação da população habitante na área rural em virtude do atraso técnico, da concentração fundiária e da insuficiência de crédito. Para alterar tal realidade social, os bispos sugeriram, entre diversas propostas, a fixação do homem ao meio através do lote agrícola e que os usineiros da Zona da Mata:

a) permitam que parte de áreas de terras dessas usinas, localizada perto das casas dos trabalhadores e porventura não-coberta de canaviais, seja por eles utilizada na produção de gêneros de alimentação básica para eles e para suas famílias; b) as usinas, tendo em vista o aproveitamento racional econômico das áreas não-trabalhadas com a cultura da cana, realizem, diretamente, explorações de outras culturas, especialmente produtos de alimentação, possibilitando, assim, melhorar o sistema de abastecimento da Zona da Mata e a fixação de trabalhadores na área do açúcar; c) haja esforço ainda bem maior por parte de determinados usineiros no sentido de humanizar as condições de vida desse grande grupo de menos afortunados da população trabalhadora rural da economia da agroindústria do açúcar, em certos casos, a viverem em condições terrivelmente difíceis (CNBB, 1981b, p. 93).

Contudo, as considerações da Igreja Católica sobre a reforma agrária, diante da crescente influência do Partido Comunista e das Ligas Camponesas no interior do nordeste brasileiro, a partir de 1961, ressaltam o caráter defensivo da Igreja, cuja preocupação central de manter sua influência na sociedade torna secundária a preocupação com a questão agrária. Fato indicativo dessa alteração, a Comissão Central da CNBB, em uma reunião extraordinária em 03 e 05 de outubro de 1961, sob a presidência de D. Jaime de Barros e com a presença do núncio apostólico, D. Armando Lombardi, elaborou a declaração A Igreja $e$ a situação do meio rural brasileiro, o qual dava ênfase à lógica produtivista no meio rural e o pequeno agricultor como sócio desse processo.

\section{Uma guinada para a modernização e ao desenvolvimentismo: do agrário para o agrícola}

No documento informado anteriormente, uma ausência chama a atenção: a referência ao sistema de posse e uso da terra e a reforma agrária. Essa Declaração episcopal destacava a necessidade de integrar a agricultura brasileira ao ritmo do desenvolvimento nacional, enfatizando os seguintes aspectos: melhoramento das condições de infraestrutura; transformações nas técnicas de produção; aproveitamento de mão-de-obra liberada pela modernização; promoção de uma política econômica, abrangendo o regime fiscal, o crédito seguro social, o controle dos preços e o desenvolvimento das indústrias de transformação, a modernização dos estabelecimentos agrícolas; reafirmação do estabelecimento familiar como ideal de estabelecimento agrícola; apoio à organização profissional dos agricultores; g) eliminação das disparidades regionais (CNBB, 1981c, p. 122-125).

Percebem-se pelos documentos tornados públicos uma preocupação da oficialidade da Igreja Católica com o desenvolvimento e o progresso agrícola; a dimensão agrária anterior cede espaço à agrícola, ou seja, à produção, crédito, incentivos, preços, tecnologia, proteção do estado, etc., em correspondência com o modelo econômico desenvolvimentista que se consolidava no país atrelado ao capital estrangeiro, aos processos de internalização de capitais internacionais (via multinacionalização) e ao macro pacote tecnológico denominado de revolução verde, subsidiado por agências de fomento, bancos e empresas agroindustriais norte-americanas. $\mathrm{Ou}$ seja, dimensões políticas, de disputas de espaço, 
poder e tutela no meio rural, aliam-se às de cunho econômico e mercadológico.

Tanto a Revolução Cubana de 1959, quanto a eleição de Jânio (1961) e a posse de João Goulart (1963) contribuíram em muito para que houvesse uma "guinada conservadora" no interior da Igreja Católica (BEOZZO, 1994). Grupos conservadores atuaram com força no meio social através de marchas, manifestações populares, uso de rádios e jornais para disseminar o perigo comunista, a defesa da fé, da liberdade e da família. Foi um período, sem dúvida, de grande envolvimento da Igreja Católica com a dimensão política e ideológica dos rumos do país. Isso tudo vai se refletir na sua ação no meio rural e nos combates aos movimentos sociais que possuem certa base política de cunho marxista, ou que se imaginava que tinham dimensões nesse campo. Essas ações revelavam a não existência de consenso no interior da referida instituição. Fatos políticos vão revelando as múltiplas faces do campo eclesial brasileiro no período.

Em tom de disputa com o PCB e as Ligas Camponesas, houve, no interior das pastorais sociais da CNBB, uma tentativa de demonstrar forte apoio e presença da referida instituição no meio rural através da Juventude Católica Rural (JAC) e da Liga Eleitoral Católica (LEC); da sindicalização; das Frentes Agrárias e do Movimento de Educação de Base (MEB) (CNBB, 1981c, p. 126). Além de alertar e exortar o clero a assumir uma postura ativa no combate aos comunistas:

Os comunistas, no campo como na cidade, não se interessam realmente pelas soluções. Ao contrário: para eles, quanto pior, melhor. Mas o fato mais grave que denunciamos é que os agitadores vermelhos, em várias frentes, preparam-se para a tática de guerrilha de acordo com os melhores exemplos cubanos ou chineses. Assim como não podemos parar no mero anticomunismo simplista e contraproducente, não podemos ser ingênuos a ponto de entregar-nos a grandiosos planos de recuperação econômico-social dos meios rurais, esquecidos da retaguarda e dos flancos invadidos pelos guerrilheiros. Em cada diocese, caberá à perspicácia do pastor descobrir os meios práticos de defender o trabalho (CNBB, 1981c, p. 127).

A CNBB, em 1963, pronuncia-se na defesa da reforma agrária, ao apoiar a emenda constitucional que permitia a desapropriação por interesse social com indenização total ou parcial em dinheiro ou em títulos da dívida pública (CNBB, 1981d). É importante destacar que esse posicionamento não teve caráter unânime do episcopado. Vozes dissonantes, disputas ideológicas, filosofia religiosa, poderes regionais e descentralizados, como foi o caso do cardeal Dom Vicente Scherer no Rio Grande do Sul, áreas prioritárias de atuação, apoio ao golpe civil-militar de 1964, dentre uma série de outros aspectos que aqui não temos condições de enfatizar e nem de aprofundar, marcaram as multifaces da entidade. Nesse sentido, para a questão que estamos desenvolvendo, formou-se um pequeno grupo contrário à reforma agrária e discordante das posições oficiais da CNBB, liderado pelos bispos D. Proença Sigaud e D. Castro Mayer (LENZ, 2002, p. 600). Numa perspectiva mais de ação, num âmbito regional, o cardeal Dom Vicente Scherer sempre se posicionou contrário à reforma agrária e às diretrizes que documentos da CNBB evidenciavam no período. $\mathrm{O}$ referido líder religioso criou um órgão promotor da organização dos pequenos agricultores, denominado de FAG (Frente Agrária Gaúcha), com a intenção de criar organizações sindicais, concorrer com o PTB, PCB e Ligas Camponesas na tutela dos pequenos agricultores. Nesse sentido, destacamos, também, a carta pastoral de Dom Inocêncio, bispo de Minas Gerais, o qual menciona o grande perigo comunista que a Igreja alardeava: "E os agitadores estão chegando ao campo. Se agirem com inteligência, nem vão ter necessidade de inverter coisa alguma. Bastará que comentem a realidade, que ponham a nu a situação em que vivem ou vegetam os trabalhadores rurais" (CNBB, 1976).

Muitos outros documentos na década e 1960 reiteram o caráter preventivo e anticomunista da Igreja Católica, preocupada em manter o controle sobre os trabalhadores rurais. Destacamos depoimento de um bispo de São Paulo em 1960: "Quando o comunismo vos convidar para grupos 
e ligas de defesa dos vossos interesses, já deveis estar organizados em núcleos democráticos e construtivos que desejamos ajudar a criar" (CNBB, 1960, p. 109). Segundo Salem (1981), os bispos reformistas também se alarmaram com o perigo da "cubanização" ou do comunismo do país e apoiaram o golpe como uma espécie de saída segura, preventiva.

\section{Ambiguidades e ambivalências frente às ações repressivas do regime militar}

No decorrer do Regime Militar, em especial a partir de 1970, a Igreja Católica transita de uma postura defensiva a uma mais ativa em relação aos temas sociais, sobretudo no que tange à reforma agrária (LENZ, 2002). Investida de uma intervenção social proativa, a Igreja entra em conflito com o Estado, segundo Lenz (2002), esse choque ocorreu em virtude de a Igreja discordar do caráter do Estado (militar-tecnocrático), que defendia critérios de modernização e racionalização no trato da questão agrária (LENZ, 2002, p. 601).

Essa realidade política e social deixava a Igreja Católica, em sua oficialidade, muito apreensiva, pois além da possibilidade de alterar quadros de adeptos em seu horizonte ideológico, poderia abrir espaços para facções ou grupos de outra roupagem em seu interior, os quais estavam desenvolvendo ações em adequação às demandas dos camponeses como é o caso da Ação Popular (AP) e da Ação Católica (AC) (ALVES, 1979; BASTOS, 1984). Expressivo disso foi o documento escrito pela Comissão Central da CNBB, em junho de 1964, logo após o golpe, o qual deixou explícito seu apoio à ação militar no país.

O Brasil foi há pouco cenário de graves acontecimentos que modificaram profundamente os rumos da situação nacional. Atendendo à geral e angustiosa expectativa do povo brasileiro, que via a marcha acelerada do comunismo para a conquista do poder, as Forças Armadas acudiram em tempo e evitaram que se consumasse a implantação do regime bolchevista em nossa terra. [...]. Logo após o movimento vitorioso da revolução, verificou-se uma sensação de alívio e de esperança, sobretudo e quase desespero em que se encontravam as diferentes classes e grupos sociais, a proteção divina se faz sentir [...]. Ao rendermos graças a Deus que atendeu às orações de milhões de brasileiros e nos livrou do perigo comunista, agradecemos aos militares que, com grave risco de suas vidas, se levantaram em nome dos supremos interesses da nação e gratos somos a quantos concorreram para libertarem-na do abismo iminente" (REB, 1964, p. 491, Grifo nosso).

Não obstante, ainda no início do golpe militar, a CNBB alertava para as injustiças. Dom Hélder Câmara, que, em abril de 1964, assumiu como arcebispo de Olinda-Recife, era a voz forte nessa dimensão social da Igreja e nas ressalvas quanto à visão tradicional da cristandade e do próprio golpe e regime militar de governo. As divergências no episcopado e na oficialidade da Igreja passaram a ser notórias, estando a Igreja Católica, em meados da década de 1960, numa espécie de "encruzilhada histórica" (BEOZZO, 1994). A Ação Popular (AP), criada em 61, oriunda desses conflitos entre o episcopado e lideranças de movimentos no interior da própria instituição, passou a ser um quadro de grande expressão na formação de lideranças de esquerda na política brasileira. Porém, com o passar dos anos do golpe civil-militar, a AP foi minada por dentro, suas lideranças reprimidas, bem como foram desarticulados vários movimentos independentes, mas de inspiração católica.

Em 1968, com o Concílio de Medellín na Colômbia, a Igreja latino-americana reafirmou as bases da doutrina social inaugurada com o Concilio Vaticano II (1962-5), principalmente em torno da consciência para os problemas sociais, as questões de âmbito cultural (em especial os povos indígenas) e novos caminhos para pastorais sensíveis à realidade dos pobres do continente. Os camponeses estavam no início da fila deste "compromisso com os pobres" (CELAM, 1980, p.12).

A Igreja Católica, em sua oficialidade, tinha receio de perder seu prestígio; os militares eram anticomunistas e defensores da "civilização ocidental 
cristã" (MAINWARING, 1989). Porém, aos poucos, os militares mostraram sua face, suas práticas e para quem estavam governando. Seus acordos com os grandes capitais (nacionais e internacionais), seu endurecimento político, sua centralidade política, a "guerra" contra os direitos humanos fundamentais dos cidadãos, produziam certo descontentamento na oficialidade da Igreja Católica. Um documento da CNBB de 1969, após o AI-5, deixa claro que

“[...] é firmado o direito da Igreja de pronunciar-se sobre assuntos políticos quando estiver em questão o bem da população. [...]. A situação institucionalizada no mês de dezembro [AI-5] possibilita arbitrariedades, entre as quais a violação de direitos fundamentais, como o de defesa, de legitima expressão do pensamento e de informação; ameaça à dignidade da pessoa humana [...], institui um amplo poder que torna muito difícil o diálogo autentico entre governantes e governados" (CENTRO DE PASTORAL VERGUEIRO, 1986, p.120).

Esse documento do final da década de 1960 apresenta uma ideia da mudança que foi se constituindo na relação entre Igreja e Estado no período. Membros da Igreja foram reprimidos, acusados de "agentes do comunismo". A própria Igreja se viu na iminência de redefinir sua aliança com o regime e com as classes dominantes que o sustentavam (MATOS, 2003).

O golpe militar de 1964 veio a fortalecer essa tendência repressiva aos camponeses pela dimensão governamental e deu à questão agrária outro enquadramento, numa tentativa de despolitizá-la, visto que os militares impuseram ao Congresso Nacional uma modificação constitucional que viabilizasse a reforma agrária (o Estatuto da Terra).

"O Estatuto da Terra seria, na verdade, um instrumento de modernização do campo e de estímulo à disseminação da empresa rural. Condenava-se o latifúndio e também o minifúndio, isto é, a agricultura praticada por grande número de pequenos lavradores no país. De fato, o governo militar propunha, pelo Estatuto da Terra, uma intervenção no direito de propriedade e no meio rural para favorecer a expansão da empresa capitalista, particularmente os grandes grupos econômicos" (MARTINS, 1989, p. 48).

Contrapondo-se, pelo menos em parte, frente aos processos excludentes da modernização socioeconômica em andamento pelo Regime Militar, a Igreja Católica evoca o direito natural e a dignidade da pessoa humana para defender os direitos humanos como anteriores a qualquer ordenamento jurídico do Estado. Enquanto uma amostra precisa da incompatibilidade da concepção de política encarnada pela Igreja com o modelo de desenvolvimento econômico do Regime Militar, o qual negligenciava os direitos humanos, destaca-se o documento elaborado pela $15^{\circ}$ Assembleia Geral da CNBB, Exigências cristãs de uma ordem política (CNBB, 1977), o qual enfatiza a "clara precedência de humanos, individuais e sociais, baseados no direito natural, portanto, anteriores a qualquer ordenamento jurídico e que esse ordenamento apenas reconhece, não cria". Também se observa, no posicionamento da Igreja frente ao Estado, a defesa de uma nova ordem social baseada nos valores de justiça e solidariedade. Lenz (2002) sintetiza a concepção dessa nova sociedade da seguinte forma:

A Igreja dizia ter consciência de agir motivada por uma visão de fé inspirada no testemunho cristão. Sob o influxo da inspiração brotada do Concílio Vaticano II e dos posicionamentos das Conferências do Celam, ${ }^{1}$ os documentos desse período se destacam por uma visão antropológica, que tem em vista o homem todo; por uma doutrina social, baseada numa visão filosófica e transcendente da vida humana, desembocando num projeto de sociedade, orientado a uma ampla transformação econômica e social, tendo como base e meta o ser humano, dando prioridade ao trabalho sobre o capital, unindo políticas de crescimento com políticas sociais e participativas (LENZ, 2002, p. 601).

Motivado pelas disputas de terras entre posseiros e os latifundiários, nas quais a Igreja Católica se fazia presente, sobretudo na Amazônia 
e no sul do Brasil, havia, no final da década de 1970, uma organização de sem-terra que se negavam a aderir ao programa governamental de colonização da Amazônia. Nesse sentido, havia o apoio de agentes de pastoral, bem como de religiosos e religiosas na organização de meeiros e outras categorias de trabalhadores da região Nordeste. Como expressão disso, a $18^{\circ}$ Assembleia Geral da CNBB produziu o documento "Igreja e Problemas da Terra" (CNBB, 1980). Na primeira parte do documento, os bispos fazem uma crítica contundente ao modelo de modernização do campo implantado no país, a partir de 1973, que resultam na concentração do capital e do poder, advertindo:

[...] desejo incontrolado de lucros leva a concentrar os bens produzidos com o trabalho de todos nas mãos de pouca gente. Concentram-se bens, o capital, propriedade da terra e seus recursos, concentrando-se ainda mais o poder político, num processo cumulativo resultante da exploração do trabalho e marginalização social e política da maior parte do nosso povo (CNBB, 1980 , p. 142).

Em decorrência desse processo, as populações constituídas por trabalhadores rurais que "não conseguem continuar como posseiros, arrendatários, colonos, parceiros, moradores; transformam-se em proletários, em trabalhadores à procura de trabalho, não só no campo, mas na cidade" (CNBB, 1980 , p. 144). ${ }^{2} \mathrm{Na}$ segunda parte do referido documento, a abordagem caracterizase pelo cunho doutrinal. Os bispos reafirmam a concepção da Igreja referente à propriedade, a qual concebe a terra como um dom de Deus em benefício de todos, fazendo alusão à doutrina de Santo Tomás, segundo a qual a apropriação individual é um dos meios para realizar a destinação universal dos bens a todos. Também fazem menção ao Concílio Vaticano II e citam uma afirmação de João Paulo II: "Sobre toda a propriedade privada pesa uma hipoteca social" (CNBB, 1980, p. 150).

O documento menciona o fato de a terra de trabalho ser um direito popular de propriedade familiar, tribal, comunitária e de posse, e ressalta a relevância social das formas de produção alternativas ao modelo capitalista enquanto uma experiência social que respeita a dignidade humana e os direitos dos trabalhadores:

Formas de propriedade, alternativas à exploração capitalista, abrem claramente um amplo caminho, que viabiliza o trabalho comunitário, até em áreas extensas, e a utilização de uma tecnologia adequada, tornando dispensável a exploração do trabalho alheio. Há no país uma clara oposição entre dois tipos de propriedade. De um lado, o regime que leva o conflito aos lavradores e trabalhadores rurais, que é a propriedade capitalista; de outro, aqueles regimes alternativos de propriedade, mencionados antes, que estão sendo destruídos ou mutilados pelo capital: o da propriedade familiar, como os lavradores do sul e de outras regiões; o da posse, no qual a terra é concebida como propriedade de todos e cujos frutos pertencem à família que nela trabalha, regime difundido em todo país e, sobretudo, na Amazônia Legal; a propriedade tribal e comunitária dos povos indígenas e de algumas comunidades rurais $(\mathrm{CNBB}$, 1980, p. 152, Grifo nosso).

Aprofundando a análise acerca da realidade social do campo brasileiro, os bispos, de uma ala do campo eclesiástico, enfatizam a função social da denominada propriedade privada da terra, a qual se opõe ao conceito de propriedade capitalista. Segundo os bispos que assinaram o documento, a propriedade privada da terra "é usada como instrumento do próprio trabalhador e de sua família, ou cultivada pelo proprietário com mão-deobra assalariada, tendo função social e respeitando os direitos fundamentais do trabalhador" (CNBB, 1980, p. 151); ao passo que, a propriedade capitalista notabiliza-se "como instrumento de exploração do trabalho alheio" (CNBB, 1980, p. 151). A terceira parte do documento é marcada pelo tom de proposição e mobilização da Igreja Católica diante do quadro de deterioração da dignidade humana em virtude da modernização agrícola. Os bispos assumem sete compromissos pastorais: submeter terras possuídas pela instituição religiosa a um estudo quanto ao seu uso adequado; denunciar 
as situações abertamente injustas e as violências que se cometem no campo; apoiar os esforços por uma autêntica reforma agrária; defender as legítimas aspirações dos trabalhadores urbanos; condenar tanto o capitalismo como o coletivismo marxista; aprofundar as comunidades eclesiais de base, rurais e urbanas; e vivenciar o Evangelho (CNBB, 1980, p. 155). O documento ilustra a ameaça do desenvolvimento de novas formas de neocolonialismo referindo-se aos grandes projetos de produção de grãos na região centro oeste do país. Finalizando o texto, os bispos que assinam o documento destacam que, para alterar a realidade de injustiça e exploração do trabalho da maioria do povo, é necessário mudar a mentalidade e a estrutura de funcionamento de nossa sociedade, pois, enquanto

[...] o sistema político-econômico estiver a favor dos lucros do pequeno número de capitalistas, e enquanto o modelo educacional servir de instrumento de manutenção desse sistema, inclusive desestimulando a vida rural e seus valores, então não terá solução verdadeira a situação de injustiça e de exploração do trabalho da maioria (CNBB, 1980, p. 156).

A Igreja Católica, de uma geral, queria reformas pelas quais as barreiras de resistência do latifúndio atrasado fossem rompidas e que desenvolvimento econômico quebrasse aquelas velhas relações de dependência e pobreza. Além disso, o regime militar distanciou-se da Igreja ao perseguir membros da entidade católica. Martins (1994, p. 118) afirma que,

Neste desencontro, os rumos da Igreja se separam dos rumos do Estado, fato que ficará claro a partir de 1968 com o início de um longo e doloroso ciclo de prisões de religiosos e cristãos engajados, além do assassinato, em 1969, do padre Antônio Henrique, justamente auxiliar de dom Hélder Câmara.

A ditadura desencadeou a repressão no campo, fazendo cessar, aparentemente, a desordem rural e, ao mesmo tempo em que caçava as lideranças dos movimentos sociais, criava, em princípio, as condições para a realização de uma reforma no direito de propriedade da terra. A repressão incidiu sobre um aspecto particular da ação dos católicos: a educação e a conscientização dos camponeses.

\section{Entre a repressão e a organização social: a construção de amplas representações dos agricultores}

Em meados 1970 surge a CPT produzida e legitimada no interior de pastorais sociais do meio rural. $\mathrm{O}$ objetivo da mesma era auxiliar na organização da luta pela reforma agrária, contra a usurpação da terra camponesa em várias regiões do país, em especial no centro-norte, evangelizar a luta social pela terra, fundamentando-a na liturgia cristão-católica, na tradição bíblica e na cultura camponesa em geral. Em decorrência das condições sociais e políticas violentas e brutais, a Igreja Católica criou, em 1972, o Conselho Indigenista Missionário (CIMI), que reformularia inteiramente a pastoral indígena, e em 1975, a Comissão Pastoral da Terra (CPT), para articular o trabalho das diversas regiões em favor dos direitos dos trabalhadores rurais (MARTINS, 1994; CARINI, 2005). Ainda, a instituição mobilizou-se para combater as questões do capitalismo e da violência no campo com documentos episcopais com o objetivo de ganhar mais força e poder. Nesse contexto, a CNBB destacava que

A Igreja vigilante está atenta aos direitos humanos, comprometida com os direitos dos pobres e oprimidos, voz dos que não têm voz. Uma Igreja comprometida com a dignidade do homem e consciente de que a libertação dos pobres passa pelo rompimento das cadeias que escravizam não só o seu trabalho, mas também a sua consciência (CNBB, 1979, p.6).

A partir do final da década de 1970, a Igreja Evangélica de Confissão Luterana no Brasil aligouse com mais intensidade ao campo religioso sensível às demandas dos subalternizados, em particular, também no meio rural junto a indígenas e pequenos 
agricultores. Ela organizou sínodos, encontros ecumênicos, os quais acentuavam a opção pelos pobres. Motivadas por estas opções eclesiais, ainda em pleno regime de repressão, lideranças e setores religiosos empreenderam iniciativas de trabalho junto às camadas mais pobres da população com o chamado trabalho de "conscientização de base". Estas pastorais específicas e pioneiras, junto com outros setores, trabalharam na conscientização das pessoas e fortaleceram iniciativas de organização social. No final da década de 1970, quando o regime militar dava sinais de enfraquecimento, iniciaram novos movimentos sociais populares, em particular, no campo do sindicalismo entendido como "combativo", ou o "novo sindicalismo" (BASSANI, 1986).

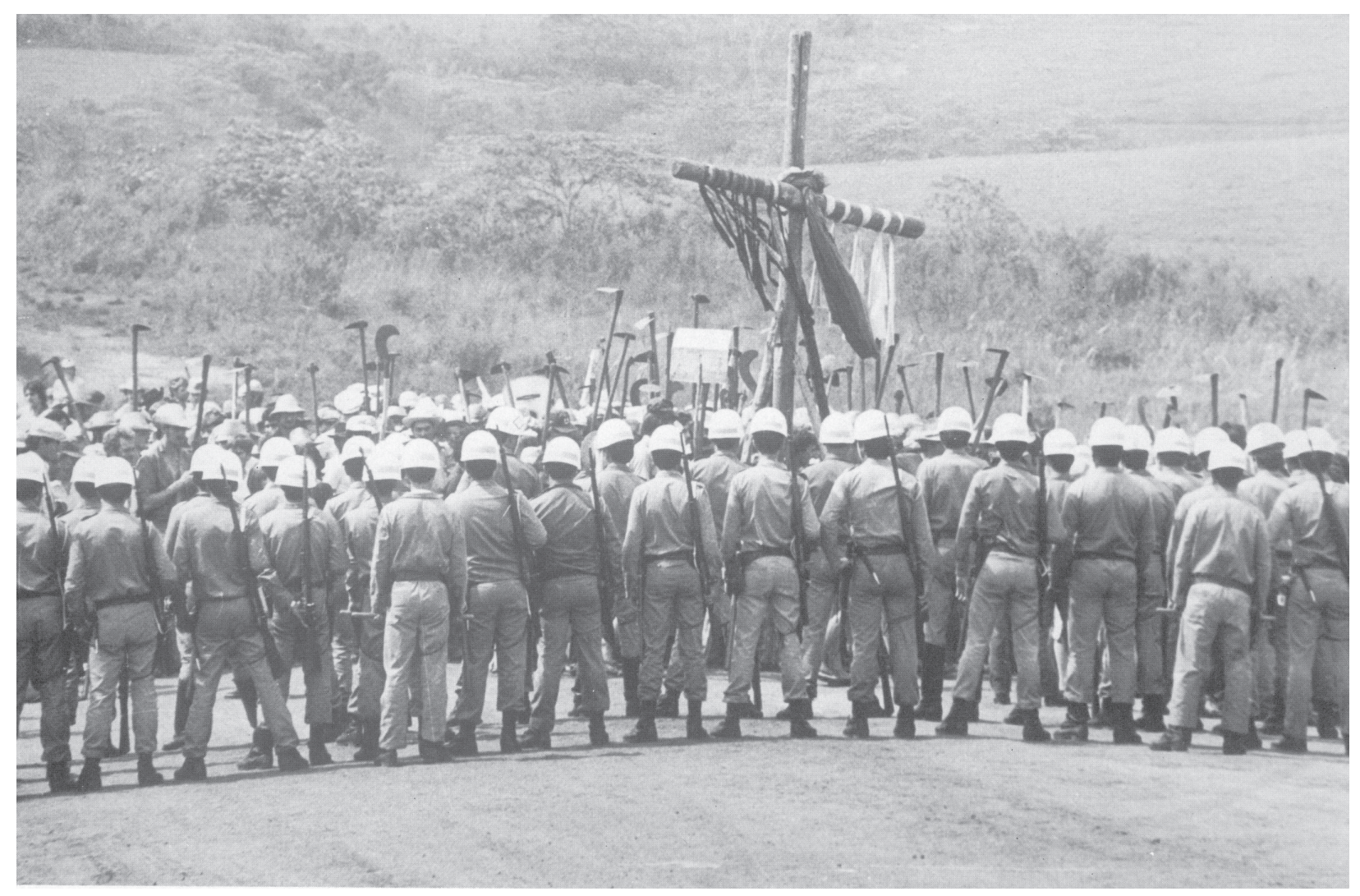

Figura 1: A presença das forças militares em acampamento no norte do Rio Grande do Sul, em agosto de 1983. Fonte: Daniel de Andrade. A luta dos trabalhadores Sem-terra. Álbum de fotografias.

Na década de 1970, uma ala da CNBB assume com veemência a luta pela terra e busca fazer valer o Estatuto da Terra (de 1964). Nessa liderança está D. Helder Câmara, bem como alguns bispos no Sul do Brasil. No entanto, D. Vicente, já como cardeal, manteve-se irredutível e assumiu para si a fundamentação ideológica e prática da FAG no Estado que, não obstante, não destoava em vários outros aspectos da oficialidade da Igreja Católica no Brasil, principalmente em torno do combate às orientações marxistas.

O golpe civil-militar de 1964 encarregou-se, por toda a década de 1970 de dificultar e/ou romper com o processo de organização dos trabalhadores de até então em nível de país. $\mathrm{O}$ mesmo extinguiu definitivamente as Ligas, manteve o sindicalismo rural no interior da Igreja Católica, ou melhor, confiando em sua mediação (DALLA NORA, 2002). Porém, no final da década de 1970, conflitos sociais em torno da questão da terra eclodiram. Alguns contra o latifúndio, outros envolvendo indígenas, muitos deles contra o estado, exigindo a aplicação do Estatuto da Terra (esse, elaborado em 1964 pelos militares), incorporação de direitos sociais, seguridade social, etc. Muitos desses conflitos eram mediados pelas ações pastorais, em particular, a 
Comissão Pastoral da Terra, o Conselho Indigenista Missionário, as Comunidades de Base, essas em gestação, dentre outras mediações políticas que foram se constituindo.

No início dos anos 80, a principal agremiação de luta social pela terra e de grande mediação da ala progressista e combativa da Igreja Católica, é o MST. Esse é fruto de uma construção social mediada por atores sociais representativos da Teologia da Libertação. $\mathrm{O}$ arcabouço teórico do Movimento é delimitado originariamente a partir da influência do trabalho pastoral e do ideário da Teologia da Libertação. No entanto, esse encontro não foi refratário às contradições. Os conceitos centrais da Teologia da Libertação: autonomia, transformação social, protagonismo histórico contribuíram para o processo de distanciamento do Movimento do campo de influência da Igreja.

Na década de 1980, a oficialidade da Igreja Católica reafirma sua opção pelos pobres, adentrando para a discussão dos direitos humanos, pela oposição sindical, pela luta pela redemocratização do país, da pobreza que se generaliza, pela reorganização social e política, pelo Estado de Direito e contra as ações do FMI. Documentos da CNBB são elaborados nesse sentido dando ênfase à conjuntura política, à sua missão evangelizadora, aos valores éticos e de justiça, à necessidade de reconstituir instituições democráticas. O trabalho da Igreja junto ao Movimento dos Sem Terra (MST), na sua origem, foi coerente com a Doutrina Social da Igreja e inspirado na prática da Teologia da Libertação. Exaltava a população degradada pela expansão e aceleração do modelo de desenvolvimento baseado na internacionalização desmedida do capital a organizar-se para estabelecer outro modelo de desenvolvimento, considerado mais justo e que contemple os subalternizados do meio rural. Nesse processo de construção, era relevante que os oprimidos assumissem a sua autonomia política e intelectual, ou seja, entendessem a realidade que lhes cercava em todas as suas dimensões; mais precisamente, as causas e os mecanismos de manutenção da exclusão econômica, social e política da população latino-americana. Tão importante quanto intervir socialmente era ter clareza e condições de pensar a práxis sem necessitar de tutela cognitiva exterior.

Nesse sentido, a transformação social era compreendida como o processo de mudança daquela sociedade, impregnada de contradições socioeconômicas em decorrência do modelo econômico. A sociedade vislumbrada pelos agentes de pastoral - a denominada "Terra Sem Males" é a antítese da sociedade capitalista. Em suma, é marcada pelo trabalho cooperativo, pela valorização do ser humano acima do material, pela existência de democracia política e econômica capaz de produzir a equidade social e pelo modelo econômico orientado para as necessidades e os interesses dos seres humanos, e não da reprodução do capital.

No entanto, por mais que esse ideário dialogasse com as concepções do MST, após sua estruturação, a partir de 1986, surge a oposição das ideias relativas à estratégia de atuação do Movimento. A metodologia de trabalho de investir em ações coletivas efetivas, caracterizadas pela ampla participação dos atores em todas as instâncias de direção, empregada pela Igreja progressista, deparase com a nova orientação do MST de estabelecer uma centralização nas decisões do movimento. $\mathrm{O}$ ideário do MST, ao valorizar a questão da autonomia política, uma herança da Igreja Católica em suas ações pastorais, estabelece, com a ela e, também, com outras instituições ligadas a ela, uma relação de distanciamento no que se refere à reflexão e à construção da leitura da realidade. 


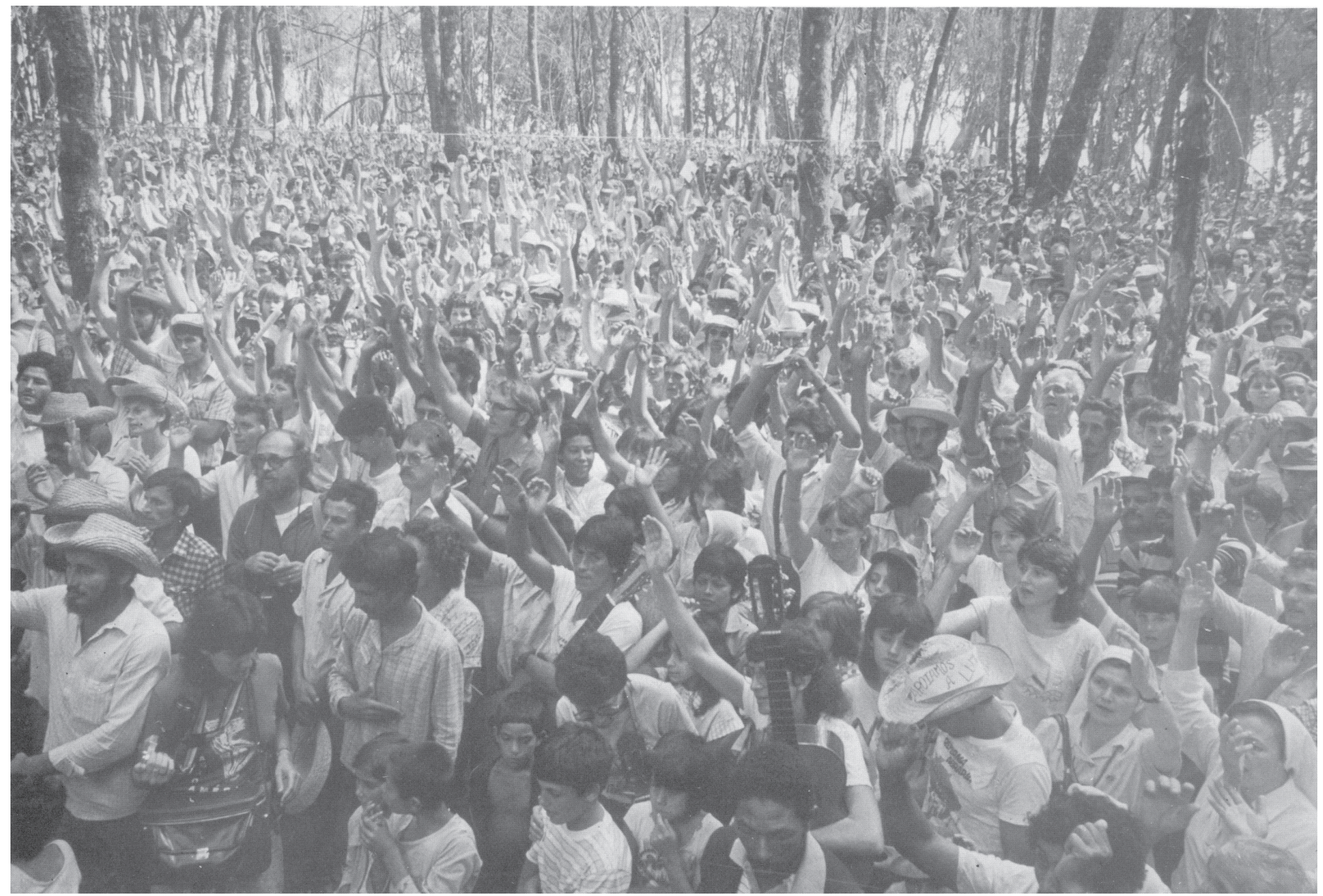

Figura 2: Romaria da Terra em 1982, na Encruzilhada Natalino, norte do RS.

Fonte: acervo pessoal do Padre Arnildo Fritzen.

Assim como a CNBB, em suas diretrizes ligadas a terra e aos pequenos agricultores, nas suas várias matizes e expressões coletivas regionais do país, o Movimento dos Agricultores Sem Terra (MST), surgido em nível de país no início da década de 1980, também nunca foi uma entidade afinada em suas múltiplas ações, estratégias, posições, representações, mediações etc. Múltiplas disputas internas deram o tom de uma entidade complexa, diferenciada, conflituosa, etc., em correspondência com a luta social pela terra. No início da década de 1990 havia um grande conflito instituído entre o MST, já consolidado enquanto agregador da luta social e política pela terra, e outros grupos mediadores. Os conflitos se manifestavam também em termos de opções de ações, metodologias e representações em quadros sociais e políticos externos e internos, em especial entre a CPT e o MST. O conteúdo das ações efetivadas pela CPT e outros representantes de igrejas não consensulizava com decisões do MST, principalmente em sua dimensão política, ritualística e de significação. A Bíblia, suas passagens em torno do sofrimento, sacrifício, da mística da cruz, começaram a ser questionadas pelo MST, bem como a presença de outras igrejas e suas interpretações variadas do campo teológico demonstravam certa redução do poder legitimador e aglutinador que a Igreja Católica até então sempre teve.

\section{Considerações finais}

Buscamos analisar alguns aspectos que denotam a preocupação e as mediações da Igreja Católica no cenário próximo à constituição de movimentos sociais de luta pela terra, dentre eles, o MST. Vimos que as medições de um grupo do campo eclesial católico junto às lutas dos pequenos agricultores tiveram várias fases e faces, expressaram conflitos, tomadas de posição, lutas internas na instituicionalidade da Igreja Católica. A primeira fase compreende antes do golpe militar 
de 1964, quando a Igreja Católica tinha uma grande preocupação em ter o controle social no meio rural, ao mesmo tempo reivindicava direitos, cidadania e justiça social para manter esse coletivo no meio rural nas atividades agrícolas. $\mathrm{O}$ objetivo era, também, fortalecer os agricultores para que permanecessem ligados à Igreja.

Contudo, com o golpe militar, esse grande medo que a Igreja tinha do avanço das facções ligadas ao comunismo acabou sendo eliminado com a repressão promovida pelos militares a todos os que destoavam de sua ideologia e do status quo político do período. Outra dimensão expressavase em meados da década de 1960, e que norteou as deliberações do Concílio Vaticano II, a qual apontava em direção ao compromisso da Igreja para com as causas populares.

Porém, em nível nacional, a oficialidade esteve atrelada às diretrizes sociais e políticas que o regime militar impôs. Mas isso tudo não se deu sem conflitos e tensões internas. Talvez esse período tenha sido um dos mais tumultuados da oficialidade da Igreja, organizada em torno da CNBB. Várias pastorais e linhas de evangelização foram acionadas com ou sem apoio da referida instituição. Grupos sociais, em suas lutas sociais, possuíam mediação de sujeitos e/ou organizações do campo eclesial e de lideranças leigas, porém sem vínculos com a oficialidade da Igreja.

Os anos 70 revelaram certa alteração e/ ou redefinição nas diretrizes da CNBB. Os seus documentos são claros no sentido de que o regime de exceção não lhe era mais de todo agradável. Muitas das práticas opressivas desse atingem lideranças do campo eclesiástico ou ações do campo religioso em prol dos excluídos, doutrinas e rituais. Narrativas em torno de noções como libertação, exclusão, liberdade, reformas, direitos e organização popular eram constantes nessa nova dimensão teológica e evangélica, bem como elementos do campo social estrutural (economia, dependência estrangeira, multinacionalização, imperialismo, dentre outras) e da hierarquia e do vínculo com o estado e o poder no interior da própria Igreja Católica.

Essa nova dimensão que alia macroquestões da sociedade brasileira com as pastorais sociais, constituiu importantes espaços para os trabalhadores rurais e urbanos lutarem contra as injustiças e por seus direitos. A CPT, principalmente a partir de 1979, com ampla expressão no interior do país, orientou a formação das lideranças que conduziram a organização dos sem-terra, que passariam a pressionar as autoridades para o assentamento de reforma agrária. Assim, a Igreja Católica, através de um campo eclesiástico unido em torno da CPT, passou a ser o alicerce fundamental na constituição dos MST.

A partir de meados dos anos 80, novas dimensões políticas e outras mediações, em particular, a partidária, redefiniram o papel central da Igreja Católica junto ao coletivo do MST em nível de Brasil. Ela foi perdendo espaços para outros grupos, os quais passam a racionalizar as ações do campo religioso e adentrando mais para esferas político-partidárias. Esse processo revelou uma reconfiguração do MST, em suas diretrizes, ações e pedagogia de orientação coletiva. Porém, essa nova realidade revelou, também, novas dimensões presentes no próprio interior da Igreja Católica e de outras que, sem sombra de dúvidas, alteraram seus quadros de mediação, seus vínculos institucionais com determinados movimentos sociais, um deles foi a luta pela terra na esteira da reforma agrária. No entanto, é bom que se ressalve e se enfatize que muitos dos rituais e ações produzidas no interior dos acampamentos de luta pela reforma agrária são ainda hoje os que foram cristalizados nos anos 80 quando o campo religioso, organizado e determinado por um campo eclesiástico específico, os disseminava.

\section{Notas}

$1 \mathrm{O}$ autor refere-se às Conferências Episcopais de Medellín (1968) e Puebla (1979), nas quais a Igreja Católica firma a opção preferencial pelos pobres e sua leitura da realidade social à luz de uma ética cristã, libertadora e evangelizadora.

2 Os lavradores, assalariados, posseiros, arrendatários, meeiros, peões de estância, agregados, dentre outros que, em termos quantitativos, somavam centenas de milhares em todo o Brasil por toda a década de 50, eram os sujeitos e atores sociais que expressavam as contradições da propriedade e viram-se excluídos pelas novas diretrizes 
políticas e econômicas do país. Esse processo todo foi agregado e matéria-prima para as lutas sociais, em particular das Ligas Camponesas. No seu conjunto e em suas especificidades, as lutas sociais pela terra no período revelavam o lado contraditório e atrasado da estrutura latifundista e irracional em termos econômicos. No Rio Grande do Sul, segundo o IBGE, eram contabilizados em mais de duas centenas de milhares, contingente considerado imenso num estado de colonização oficial e de performance agrícola em termos econômicos no período (GEHLEN, 1983)

\section{Referências}

ALVES, Márcio Moreira. A Igreja e a política no Brasil. São Paulo: Brasiliense, 1979.

BARROS, Raimundo. Bispos na primavera de renovação que marcou a gênese da CNBB. Revista Encontros Teológicos, 17, n. 32, p. 78-82, 2002.

BASSANI, Paulo. Frente Agrária Gaúcha: ação política e ideológica da Igreja Católica no movimento camponês no Rio Grande do Sul. Porto Alegre: UFRGS, 1986.

BASTOS, Elide. As Ligas Camponesas. Petrópolis: Vozes, 1984.

BEOZZO, Oscar. A Igreja do Brasil: de João XXIII a João Paulo II; de Medellin a Santo Domingo. Petrópolis: Vozes, 1994. (Col. Igreja do Brasil).

BRUNEAU, Thomas. Catolicismo brasileiro em época de transição. Petrópolis: Vozes, 1979.

CARINI, Joel. Estados, índios e colonos: O conflito da reserva indígena de Serrinha - norte do Rio Grande do Sul. Passo Fundo: UPF Editora, 2005.

CELAM (Conselho Episcopal Latino-Americano). Igreja na atual transformação da América Latina à luz do Concilio. Petrópolis: Vozes, 1980.

CENTRO DE PASTORAL VERGUEIRO. As relações Igreja-Estado no Brasil. São Paulo: Loyola, 1986, v.2.

CNBB. Declaração dos Arcebispos e Bispos Presentes na Reunião das Províncias Eclesiásticas de São Paulo, São Paulo: Paulinas, 1960.
CNBB. Estudos da CNBB - Pastoral da Terra. São Paulo, Paulinas, 1976.

CNBB. Exigências cristãs de uma ordem política. São Paulo: Paulinas, 1977.

CNBB. Estudos da CNBB - Pastoral da Terra. São Paulo: Paulinas, 1979

CNBB. Igreja e Problemas da Terra - Comunicado Mensal, ano 29, n 329, CNBB, Brasília, fevereiro de 1980 .

CNBB. Dom Inocêncio Engelke. Conosco, sem nós ou contra nós se fará a reforma agrária. Campanha/ MG. 1950. In: Estudos da CNBB 11 - Pastoral da Terra. São Paulo: Edições Paulinas, 1981a.

CNBB. Declaração dos Bispos do Nordeste. Pastoral da Terra. São Paulo: Edições Paulinas, 1981b.

CNBB. Declaração da Comissão Central da CNBB. A Igreja e a situação do meio rural brasileiro. Pastoral da Terra. São Paulo: Edições Paulinas, 1981c.

CNBB. Mensagem da Comissão Central da CNBB. Pastoral da Terra. São Paulo: Edições Paulinas, 1981d.

DALLA NORA, Helenice. A organização sindical rural no Rio Grande do Sul e o surgimento do sindicato dos trabalhadores rurais de Frederico Westphalen (1960-1970). 2002. Dissertação (Mestrado em História) - Universidade de Passo Fundo, Passo Fundo, 2002.

GEHLEN, Ivaldo. Uma estratégia camponesa de conquista da terra e o Estado: o caso da Fazenda Sarandi. 1983. Dissertação (Mestrado em Sociologia) - Universidade Federal do Rio Grande do Sul, Porto alegre, 1983.

GOHN, Maria da Glória. Teoria dos movimentos sociais: paradigmas clássicos e contemporâneos. São Paulo: Edições Loyola, 2002.

HIRSCHMAN, Albert. Política econômica na América Latina. Rio de Janeiro: Fundo de Cultura, 1965. 
LENZ, Martinho Matias. Movimentos sociais no contexto de globalização: o Movimento dos Trabalhadores Rurais Sem Terra (MST): identidade, contribuição para a reforma agrária e a igreja no Brasil. 2002. Tese - Doutorado em Sociologia Universidade Gregoriana, Roma, 2002.

MAINWARING, Scott. A Igreja Católica e a política no Brasil (1916-85). São Paulo: Brasiliense, 1989.

MARTINS, José de Souza. Caminhada no chão da noite: emancipação política e libertação nos movimentos sociais do campo. São Paulo: Hucitec, 1989.

MARTINS, José de Souza. O poder do atraso: ensaios de sociologia da história lenta. São Paulo: Hucitec, 1994.
MATOS, Henrique Cristiano. Nossa História. 500 anos de presença da Igreja Católica no Brasil. Tomo 3 - período Republicano e Atualidade. São Paulo: Paulinas, 2003.

PAIVA, Vanilda. A Igreja moderna no Brasil. In: PAIVA, Vanilda (Org.). A Igreja e questão agrária. São Paulo: Edições Loyola, 1985. p. 45-76.

REB. Revista Eclesiástica Brasileira, 24, n. 2, p. 491-493, 1964 (vários outros números).

RODHEGUERO, Carla, Simone. O diabo é vermelho: imaginário anticomunista e a Igreja Católica no Rio Grande do Sul (1945-1964). Passo Fundo: Ediupf, 1998)

SALEM, Helena. (Coord.). A igreja dos oprimidos. São Paulo: Debates, 1981. (Col. Brasil Hoje, n. 3). 